\title{
覾覧車 会長·理事の手帳から
}

\section{会長 退 任 の弁}

さる 6 月 25 日の総会で，私を含む約半数の理事の任期 が満了し，新しい会長として，前副会長の成合英樹氏が 新会長に任命され，また10名の新理事が選出された。今 回からは，会長の任期を 1 年とし，ただし現副会長から 選出されることにしょうとの申し合わせが実行に移され たので，私は会長職を任期 2 年で務めた最後の人間とい うことになったのであった。

個人的なことを言わせていただくと，本学会創設時以 来の古い会員であり，原研の企画室に間借りしていた事 務局員が $2 \sim 3$ 人の時代から 40 年あまりお世話になって きた。なにしろ，所属や仕事の内容が変わっても，自分 の研究者としての研究発表や委員会活動では, まさに日 本原子力学会が常にその場を与えてくれた。たまたま私 の専門領域では他の学会での発表や討論を求めても, わ ずか数名の仲間を相手の会場でしょんぼりと発表といっ た時代を経てきたのだから，日本原子力学会の発足は嬉 しかった。そこで育てられたのだから，その恩義は親と か恩師, 先輩, 同僚, 後輩といった人々から与えられて きたものの総計に匹敵する。一方，若い生意気盛りに企 画委員を務めて当時の大先生方を恼まし，少し落ち着い たところで編集委員を務めた。その後もしばらくした ら，理事・編集委員長を務めることになり，副会長就任 は60歳前だった。適性というょりは，大学に籍を置いて いたので, 比較的時間の自由があり, 学会へのサービス に優先度を与えやすい立場を見达まれてのことだったよ うだ。しかし，その後は原子力安全委員という制約の多 い職に就いたため，卒業生が母校に頼みごとに行く心境 で学会へあれこれと面倒な協力方をお願いしたが，自分 が学会の側に立ってお手伝いする立場からは，もう開放 されたつもりでいた。

公式な制約もあったし，会長への就任可能性の打診が あれば，推薦を見送るための儀礼的なご挨拶だけと受け 止めて，光栄を謝して丁重に辞退申し上げることにして きた。それが，予期せ妙緯で会長をお引き受けするこ とになったのが 2 年余り前のことになる。今回は緊急避 難的な要請であり，その原因の一端には私も絡んでいた ので，あまり身勝手なことは言えなかった。ただし，過 去に会長が任期半ばで急逝された例もあり，原子力安全 委員 6 年余で心身ともに疲れ果てていた当時の私がすで

\section{第23代会長 住 田 健 二}

に70歳直前であり，身近い皆さんは，まだそうした余力 があるのかと心配して下さった。そこで，親しい数人の 自分と同世代の臨床医の診断を求めてから正式に受諾す るだけの慎重さで対応した。おかげさまで，学会の用務 を健康上の理由で不参加ということなしで済んだ。また 在任中は, 学会の仕事を最優先に対処できたのは, 現在 の職場の好意によるところが大きかったと感謝してい る。私が無事任期一杯務めてほっとしたのは，事務局の 皆さんや私の家族だけではなかった。

本来なら，会長としての抱負や展望を持って，十分な 心の準備をして就任すべきところであったが，かなり急 なことであったので，就任早々から個人的な意見を申し 立てることはなるべく遠虑した。しかしながら，創立 40 年を経た我が原子力学会は，良い意味でも悪い意味でも あるスタイルができあがっていた。それに乗ってお扎ば 当面は無事安泰ではあるが，やがて近い将来には大きな 壁になると心ある会員達は心配していたのであった。そ して数年前からは歴代の理事会が具体的な検討や準備を 進めて扮られ，私もその改革の大筋の趣旨においては大 賛成であった。問題はいつから実行に移すかであると判 断した。そこで, なるべくその趣旨を損ねないように早 く実現させることが私の第 1 任務と考え, 細部の仕上げ にこだわるより，全面的な推進役に終始した。「学会誌 の全面的改善」「ホームページ新設」「会員の 1 部会への 無料所属化, 社会科学面での拡充」「全国に支部設置」「標 準委員会の常置化」「倫理規程の制定」「内外の諸学会, 機関との協力強化」「YGN 活動等による若手活動の助 成」等々（順不同）といった大きな変革が次々と実施に 移され，そのための各種の新設委員会活動が急増した。

これまでの原子力学会は, 原子力分野での科学・技術 者相互間での学術情報の交換・討論の場を確保すること が責務で，そのための他分野の同種組織，機関との交流 にも努力してきたが，いわゆる開かれた場としての意識 のもとに，積極的に社会との交流を進めることも 1 つの 大きな柱となってきた。幸いにして，こうした资勢は学 会の内外斿好意的に受け入れられようとしてきた矢先 に，就任後 1 年にもなら娃期に当時の山下事務局長が 急逝されるという予想外のつまずきが起こったが，すで に走り出していた多くの併行的な改革が，さらに事務局 
全員に大きな負担を求めることになった。私の任期の初 年度後半に発生した巨額の使途不明金の発生は，事務局 長不在のこうした過渡期の混乱の隙を站らって行われた 感があり, 今から考えてもまったく許しがたい出来事 で，この原稿執筆時点ではいまだに解決していない。本 来ならば会員にその後の経過報告を直接知らせるべきで あったが，まだ捜査中ということで総会等での口頭の報 告しかできなかったのが残念である。個人的な感想で恐 縮だが，原子力安全委員在任中に発生した JCO 臨界事 故と原子力学会長在任中のこの不祥事とは, いずれも個 人的な努力で防止できることではなかったこととはい え, 責任のある立場に立っていた者として生涯の痛恨事 であった。

通常ならば，役員は初年度前半に勉強して，その後半 から年来の希望を打ち上げ，第 2 年度では実現に入ると いったコースが多いのだが，そうした前向きの提案は， あとに述べる JCO 事故調查の件以外は, 引継事項の世 話ばかりで，これという発案もできないままに私の任期 が終わってしまった。まったく情けない会長であったと 思う。また，「学会賞制度の改善」にように本来の改善 の趣旨が徹底せず，早急な対応が迫られる件も残ってし まった。せめて退任前には使途不明金問題だけでも解決 したかったのだが，それも残念ながら実現できなかっ
た。ただ 1 つ提案が認められて実現した仕事は, 学会と しての「JCO 臨界事故調査委員会設置」だけである。 これだけは，世界に対する日本の原子力人としての責務 として，政府の意慢をいいことにして，うやむやにすべ きことではない。何とか完結まで見届けたいものであ る。

せめてもの慰めは, 我が国原子力界の大パイオニアで ある向坊 隆先生への世界原子力学会協議会からのグ ローバル貢献賞の贈呈を今春，東京での協議会の機会に 実現できたことがある。まさか，その1ケ月後に先生が 急逝されるとは思いもよらなかったのだが,「平和利用」 への確固たる吾々の信念を初期から貫き通してこられた 先生の活動への世界的な仲間からの敬意をご生前に捧げ られたことは，本当に幸せであったと思っている。

最後になるが，会長選出の段階から退任の日まで，不 肖の私に与えられた会員の皆様からの支援や厳しい批判 をも含めて，この機会に心から感謝を申し上げたい。ま た多彩多忙な日常的な業務を通じて，私たち理事会を支 えていただいた泉 昌子事務局長はじめ事務局職員の皆 さんのご協力にもあらためて感謝の意を表したい。こう した裏方の努力があってこそ, 私たちの原子力学会が発 展していけるので, 各位の今後の努力をも大いに期待し ている。

(2002年 7 月 28 日記)

\section{○編集委員会への意見空口「目安箱」のご案内 $\bigcirc$}

編集委員会は，読者·会員·投稿者·査読委員等からのご意見， ご提言を頂き，よりよい学会誌・論文誌編集活動をを目指すべ く，意見空口「目安箱」を設けています。

下記のようなご意見，ご提言，お問合せがございましたら， 遠慮なくお寄せ下さい。

（1）学会誌の企画・編集および掲載記事に関するご意見，ご 提言

(2)論文誌の編集および掲載論文に関するご意見，ご提言

(3) 論文投稿者加らの査読に関するご意見, ご提言, お問合せ
（4）論文査読委員からの查読に関するご意見，ご提言，お問 合せ

(5) 新刊図書の書評の推藨

ご意見等はなるべく電子メール(meyasu@aesj.or.jp)または ホームページ (http://wwwsoc.nii.ac.jp/aesj/publication/ meyasu.html)加らお寄せ下さい。FAX·郵送でも受け付けま すので, 学会事務局宛にお送り下さい。編集委員会にて調査. 検討の後, 担当編集委員が責任をむって回答いたします。学会 誌・論文誌の編集活動への皆様の積極的な参加をお願いします。 